\title{
Analysis of different cross-frame placements to enhance torsional irregular buildings against structural failure under earthquake bidirectional loadings: A case study
}

\author{
Osman AKYÜREK ${ }^{*}$ \\ Nevsehir Haci Bektas Veli University, Faculty of Engineering and Architecture, \\ Department of Civil Engineering, Nevsehir, Turkey
}

(ORCID: 0000-0001-8161-1775)

\begin{abstract}
Cross bracing frames (CFs) are employed as traditional passive energy dissipating devices, which are placed into the moment-resisting frames of the Benchmark building picked for analysis purposes. These devices are widely used, easy to construct, and inexpensive to contribute better seismic protection for existing and new buildings than complex control systems like active/passive Tuned Mass Dampers (TMDs) and so on. Therefore, in this research, the best three-predetermined CFs placements are selected. The time history analyses are made under bi-directional seismic loads such as two orthogonal excitations of El Centro in 1940, North-Ridge in 1994, and Kocaeli, Turkey in 1999. In conclusion, obtained results find out that while CFs placements into the structure can be significantly eliminating the eccentricity in the structure plan by dissipating especially torsional responses (approximately between $30 \%$ and $50 \%$ decrease) with a right engineering design perspective like Case 3, they cannot be successful enough to reduce the torsional responses without the right design vision such as Case 1 and Case 2. Therefore, Integrating CFs placements to the structure for minimizing the structural response is not always comprehensive to make the structure durability against torsional irregularity unless placed with the right engineering decision.
\end{abstract}

Keywords: Torsional Irregularity, Time History Analysis, Performance Evaluation, Cross Frame Placement.

\section{Çift yönlü deprem yüklemeleri altında eksentrik binalar için yapısal hasarlara karşı bina performansını artırmak için farklı çapraz destek profilleri yerleşimlerinin analizi: Bir vaka çalışması}

\begin{abstract}
Öz
Çapraz Destek Profilleri (ÇDP), günümüzde özellikle eksantrik binaları deprem esnasında burulmaya karsı korumak için kullanılan yöntemlerden biridir. Bu yöntem, aktif / pasif Ayarlı Kütle Damperleri (AKD) gibi karmaşık kontrol sistemlerine kıyasla, mevcut ve yeni binalar için daha iyi bir sismik korumaya katkıda bulunmak için yaygın olarak kullanılır. Çünkü yapımı kolaydır ve uygulaması diğer yöntemlere göre daha ucuzdur. Bu nedenle, bu araştırmada, önceden belirlenmiş en iyi üç ÇDP yerleşimleri seçilerek, iki yönlü sismik yükler altında sismik analizleri, 1940'da El Centro, 1994'te North-Ridge ve Kocaeli 1999 deprem dataları altında yapılmıştır. Elde edilen sonuçlara göre ÇDP'ler yapıya yerleştirilirken Durum 3'teki gibi doğru bir mühendislik tasarım perspektifi ile birlikte yapıda burulma tepkilerini (yaklaşık olarak \%30 ile \%50 arasında) azaltarak yapı planındaki eksantrikliği önemli ölçüde ortadan kaldırabilirken, doğru tasarım vizyonu ile yerleştirilmeyen ÇDP'ler yani Durum 1 ve Durum 2'da olduğu gibi burulma etkilerini bazı yükleme durumları için azaltacak kadar başarılı olamamışlardır. Bu nedenle, yapısal tepkileri en aza indirmek için ÇDP'leri yapıya entegre etmek, doğru mühendislik perspektifi ile yapılmalıdır. Aksi takdirde ÇDP'ler yapıdaki burulma düzensizliği etkilerini azaltmadığı gibi binada burulmadan dolayı oluşabilecek yapısal hasar olasılığının da artmasına neden olabilmektedir.
\end{abstract}

Anahtar kelimeler: Çapraz Destek Profilleri, Eksentrik Binalar, Performans Analizi.

*Corresponding author: oakyurek@nevsehir.edu.tr

Received: 30.12.2020, Accepted: 08.04.2021 


\section{Introduction}

Existing building stock in Turkey mostly has an eccentric plan configuration, called torsional irregularity in the plan, that making the buildings highly vulnerable to strong dynamic excitations caused by severe earthquakes or strong winds. The torsional irregularity is mostly the main failure reason for eccentric buildings during an earthquake, which does not only have devastating effects in the torsional direction but also leads to excessive destructive forces in the lateral directions. Therefore, ignoring such irregularity in the seismic analysis may lead to unexpected damages and losses [1-3].

Seismic risk evaluation is a fundamental necessity in long-term and inclusive seismic codes since population concentration is increasing day by day in earthquake-prone areas. Consequently, understanding earthquake dynamic effects on building stocks is vital to keep the public secure and safe [4-6]. The earthquake dynamic effects on a structure induce horizontal inertia forces acting through the center of mass. At the same time, the vertical members resist these forces through the center of rigidity. In many real-life structures, these reverse forces are predominantly not coincident. The lack of coincidence between the centers of mass and rigidity produces eccentricities, which cause an undesirable torsional response. The term "lateral-torsional coupling effect (LTCE)" is used when the torsional response is coupled with the lateral response $[7,8]$.

Improvements in the structural material with the help of using advanced technologies, modern buildings become taller and taller and get more flexible utilizing innovative materials. This inclination makes the buildings more vulnerable to dynamic excitations, especially for those having torsional irregularities in the plan or elevation when torsion becomes a dominant matter. Torsional irregularity exists due to the lack of coincidence between the center of mass $(\mathrm{CM})$ and rigidity $(\mathrm{CR})$ that is the center for the distributed lateral load-bearing components in a floor $[9,10]$. Under these circumstances, the buildings have a tendency not only to rotate but also to deflect laterally in two orthogonal directions when going through dynamic loading, see Figure 1.

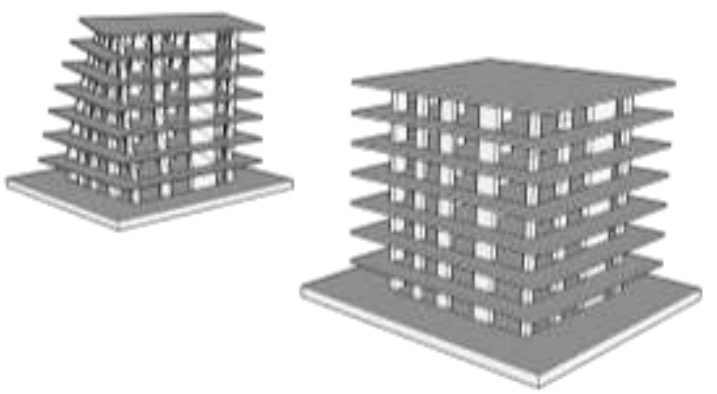

(a)
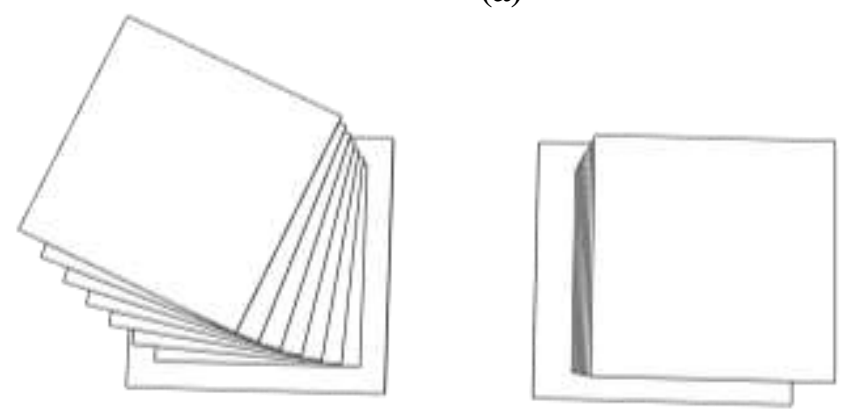

(b)

Figure 1. A demonstration of civil structure with its torsional response: (a) elevation and (b) bird's eye view [11]

A lot of modern control systems have been introduced into the literature in the last two decades to keep the structures secure when earthquakes excite them. The most widely preferred and used passive control systems by engineers and designers is a tuned mass damper (TMD) comprised of additional appropriate mass, damping, and stiffness to the primary system, excluding any external power supply [12]. However, it has some drawbacks. First, it is operative only in the fundamental tuning frequency of the structure; thus, it can be valid only in the low-frequency spectrum range. Second, it is not convenient 
for all the modes to utilize other than the tuning mode, which is generally is the first-mode of the structure because it does not have significant effects in the case of an earthquake. That is why it is first introduced multi-tuned mass dampers (MTMD) to use for eliminating the drawbacks of employing a single TMD [13]. Owing to the MTMD, it becomes more comprehended as compared to a single TMD by tuning it to different natural frequencies (modes). Therefore, it becomes more serviceable and improves stability at a wide frequency spectrum range [14-16].

Unlike the modern innovative control systems, the CFs behave as the primary members to resist the twist of the structures such as steel buildings and bridges when they are integrated into the loadcarrying systems. The bracing system is a natural and essential approach to improve the security and robustness of the buildings having torsionally irregular plan configuration when withstanding against earthquake loadings[ $[17,18]$. Because it plays a vital role in an increase not only in the load capacity by laterally and torsionally, but also reduces the absolute distance between the center of mass (CM) and rigidity (CR) when it is placed appropriately in the plan and elevation layout. It might be a v-, inverted $\mathrm{v}-$, k- or x-bracing for steel frames [19-21] or masonry infill-wall for reinforced-concrete structures [22, 23] respectively.

$\mathrm{CFs}$ placements as a structural member of the structure are expected to improve lateral load capacity and torsional loading capacity of the structure; however, sometimes they can cause to increase unevenly distributed stiffness and strength in the plan or elevation in the structure. Therefore, the study's scope is to investigate and evaluate the CFs placements, whether designed with or without a good engineering design perspective on structural performance. With this purpose, in this research, the Benchmark 9-story steel building is selected as a model structure for analysis purposes where each floor has three degrees of freedom (two translational and one rotational). There are three cross frames placements into the Benchmark 9-story steel structure's MRFs are pre-determined by the consideration of eliminating eccentricity between CM and CR of each floor. The three pre-determined cross frames (CFs) are determined by eliminating eccentricity and are employed to control undesirable lateral and torsional vibration under selected real saved earthquake ground motions. In conclusion, the research focus is on the performance evaluation of CFs placements and their contribution to the structure's performance. Integrating CFs to the structure for lessening the structural response is not always comprehensive to improve the structural stability against torsional irregularity unless placed with the right engineering decision.

\section{Material and Methods}

\subsection{Design Properties of Benchmark Building}

It has simply connected-columns to the ground, and they are made of $345 \mathrm{MPa}$ steel. It has the $9.15 \mathrm{~m}$ long-bays, which are five bays in both orthogonal directions. The columns and beams are comprised of wide-flange shapes, and the columns' orientation in the plan is demonstrated in Figure 2a. Moment frames (MFs) and simple frames (SFs) are assigned see Figure $2 \mathrm{~b}$. The interiors bays of the structure are simply connected to the composite floors, which are assigned as rigid diaphragms that provide the same response for each node within a story level during dynamic excitation. The bays and composite floor decks for each level are made of $248 \mathrm{MPa}$ steel, and they are acting together thanks to rigid diaphragms. The lumped mass of the ground level, the first level, the second through eighth levels, and the ninth level are in order $9.65 \times 105 \mathrm{~kg}, 1.01 \times 106 \mathrm{~kg}, 9.89 \times 105 \mathrm{~kg}$, and $1.07 \times 106 \mathrm{~kg}$. The total mass of the whole structure above the ground level is $9.00 \times 106 \mathrm{~kg}$. A-A axis showing columns-and beams connections is portrayed in Figure 2c. To further the structural design and structural property, the readers refer to $[24,25]$.

It is assumed that each floor has a rigid diaphragm behavior that can provide to transfer all loads directly to the columns. Each node on a floor has the same response employing the diaphragm under earthquake loadings. The structure is simplified and represented by two orthogonal ( $\mathrm{x}$ and $\mathrm{y}$ ) and one rotational $(\theta)$ degree of freedom in each story. Moreover, a $10 \%$ moment reduction at the splices is assigned, and shear deformation in elements is neglected. For moment frames (MFs) and simple frames (CFs), the lateral stiffness capacity is calculated respectively by using Eqs. (1) - (2) [26] and Eq. (3) 


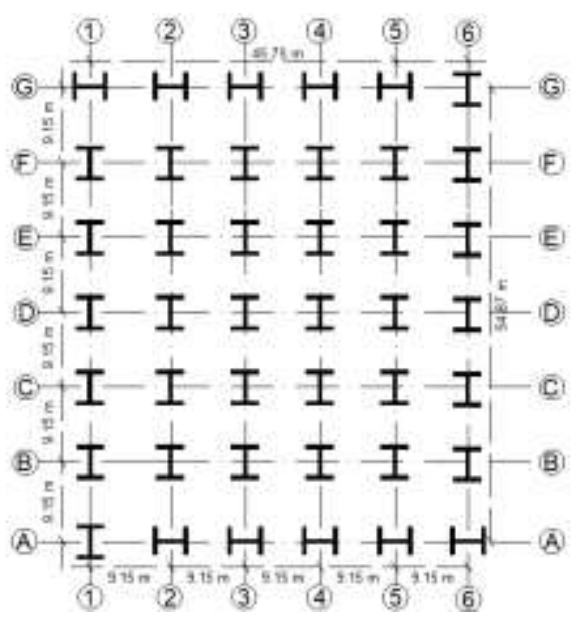

(a)

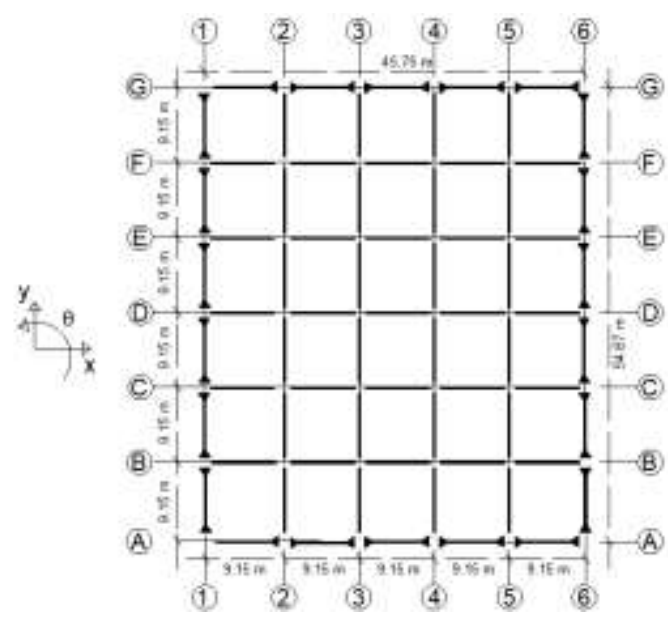

(b)

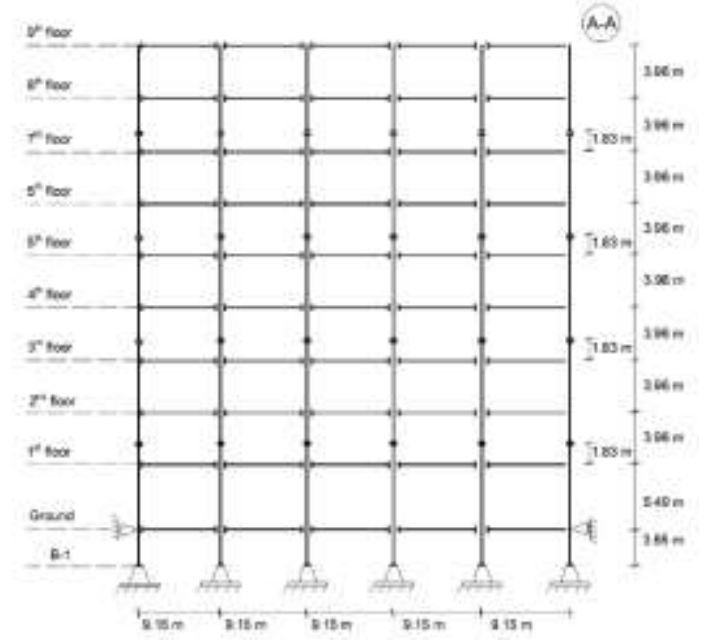

(c)

Figure 2. The structural details of Benchmark buildings modified it from [25]: (a) The orientations of columns in the plan, (b) Beams and columns connection types in the frames, and (c) Elevation-views

$$
\begin{aligned}
& k=\frac{24 E I_{c}}{h^{3}} \frac{12 \rho+1}{12 \rho+4} \\
& \rho=\frac{I_{b}}{4 I_{c}} \\
& k=\frac{3 E I_{c}}{h^{3}}
\end{aligned}
$$

where $\boldsymbol{k}$ is the equivalent stiffness For moment frames (MFs) and simple frames (CFs), $\boldsymbol{\rho}$ is the beamto-column stiffness ratio, $\boldsymbol{I}_{\boldsymbol{c}}$ and $\boldsymbol{I}_{\boldsymbol{b}}$ are the moments of inertia of the beam and columns in a moment frame (MF), and $\boldsymbol{h}$ and $\boldsymbol{E}$ are, in order, the floor height and material elasticity. The structural property of the Benchmark building with cross frames is given in Table 1. 
Table 1. The Benchmark building structural components and steel sections used in the braced frames

\begin{tabular}{|c|c|c|c|c|c|}
\hline $\begin{array}{l}\text { Story } \\
\text { no }\end{array}$ & $\begin{array}{l}\text { Heights } \\
\text { (m) }\end{array}$ & Ext. Columns & Int. Columns & Beam & Brace \\
\hline 1 & 5.49 & W14x370 & W14x500 & W36x160 & HSS $14 \times 14 \times 7 / 8$ \\
\hline 2 & 3.96 & $\mathrm{~W} 14 \times 370$ & $\mathrm{~W} 14 \times 500$ & W36x 160 & HSS $14 \times 14 \times 7 / 8$ \\
\hline 3 & 3.96 & $\mathrm{~W} 14 \times 370$ & $\mathrm{~W} 14 \times 455$ & W36x 135 & HSS $12 \times 12 \times 5 / 8$ \\
\hline 4 & 3.96 & $\mathrm{~W} 14 \times 370$ & $\mathrm{~W} 14 \times 455$ & W36x135 & HSS $12 \times 12 \times 5 / 8$ \\
\hline 5 & 3.96 & $\mathrm{~W} 14 \times 283$ & $\mathrm{~W} 14 \times 370$ & W36x 135 & HSS $12 \times 12 \times 5 / 8$ \\
\hline 6 & 3.96 & $\mathrm{~W} 14 \times 283$ & $\mathrm{~W} 14 \times 370$ & W36x 135 & HSS $12 \times 12 \times 5 / 8$ \\
\hline 7 & 3.96 & $\mathrm{~W} 14 \times 257$ & $\mathrm{~W} 14 \times 283$ & W30x99 & HSS $10 \times 10 \times 5 / 8$ \\
\hline 8 & 3.96 & $\mathrm{~W} 14 \times 257$ & $\mathrm{~W} 14 \times 283$ & W27x84 & HSS $10 \times 10 \times 5 / 8$ \\
\hline 9 & 3.96 & $\mathrm{~W} 14 \times 233$ & $\mathrm{~W} 14 \times 257$ & W24x68 & HSS $8 \times 8 \times 1 / 2$ \\
\hline
\end{tabular}

\subsection{Cross Bracing Frames into Steel Buildings}

Cross frames into moment-resisting-frames (MRFs) of a steel structure can significantly improve the safety and stability of the structure by increasing lateral and torsional load capacity. The effectiveness of the cross frame can be controlled and improved when the cross frame must satisfy the design requirements [27]. In this research, cross frames are employed to control undesirable lateral and torsional vibration under selected real saved earthquake ground motions. For simplicity in the analysis of the Benchmark building with CFs placements, the CFs are idealized by using the equivalent compression strut.

\subsubsection{Theory of the Equivalent Compression Strut}

When computing the torsional stiffness of the cross frame, an elastic truss analysis is often employed [28]. For a tension-only system, the contribution of the compression diagonal is neglected, and the single diagonal model illustrated in Figure 3 is analyzed.

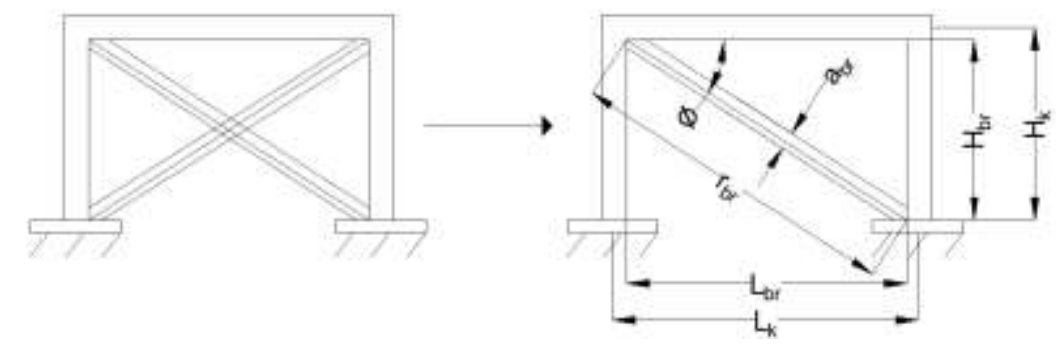

Figure 3. Cross frame design in compression

where $\boldsymbol{O}$ is the angle between the height and length of the cross-frame member. $\boldsymbol{H}_{b r}, \boldsymbol{H}_{k}$, and $\boldsymbol{L}_{\boldsymbol{b r}}, \boldsymbol{L}_{\boldsymbol{k}}$ are respectively the height and length of the equivalent compression strut and frame. The diagonal length of the cross frame is denoted as $\boldsymbol{r}_{\boldsymbol{b} r}$ in compression, the width of the strut is $\boldsymbol{a}_{\boldsymbol{b} r}$. To determine the diagonal and rotational (according to [28]) stiffness of the cross frame are respectively as:

$$
\begin{aligned}
& k_{b r}=\frac{A_{b r} E \cos ^{2}(\emptyset)}{L_{b r}} \\
& \beta_{b r}=\frac{E H_{b r}{ }^{2} L_{b r}{ }^{2}}{\frac{2 r_{b r}{ }^{3}}{A_{c}}+\frac{L_{b r}}{A_{h}}}
\end{aligned}
$$

where $\boldsymbol{k}_{\boldsymbol{b}}$ and $\boldsymbol{\beta}_{\boldsymbol{b r}}$ are the equivalent diagonal and torsional stiffness calculate when employing the cross frame into the moment frame (MF) considering only the axial stiffness of the members, $\boldsymbol{E}$ is the modulus of elasticity (200 GPa), $\boldsymbol{A}_{\boldsymbol{c}}$ and $\boldsymbol{A}_{\boldsymbol{h}}$ are respectively the area of the diagonal member and area of each strut. 


\subsection{The Selections of the CFs Placements in the Benchmark Building}

In order to mitigate not only lateral vibrations but also twisting of the structure, there are three cross frames placements into Benchmark 9-story steel structure's MRFs that are pre-determined by the consideration of eliminating eccentricity between CM and CS of each floor. As seen in see Figure 4, the placements of Case 1 in the plan view are illustrated in section a and its corresponding A-A elevation views are provided in section $b$. Cross frames (CFs) are placed from ground level to the top floor without any discontinuity in the determined frames. For this reason, for Case 2 and Case 3, there are only plan views of the placement of cross frames provided, see Figure $4 \mathrm{c}$ and Figure $4 \mathrm{~d}$. In addition, the section properties of the Benchmark building structural components and used braced frames for each floor are tabulated in Table 2. For the cross-frame placements, the HSS section is selected with different section properties for each floor. Assuming that each cross-frame strut is connected to the main-frame as a pin connection and its damping ratio is taken by a $100 \%$ increase as compared to the Benchmark structure. In this research, three different placements of the x-bracing system, (Case 1, Case 2, and Case 3) will be taken into account of seismic analysis, and the most effective placement will be determined.

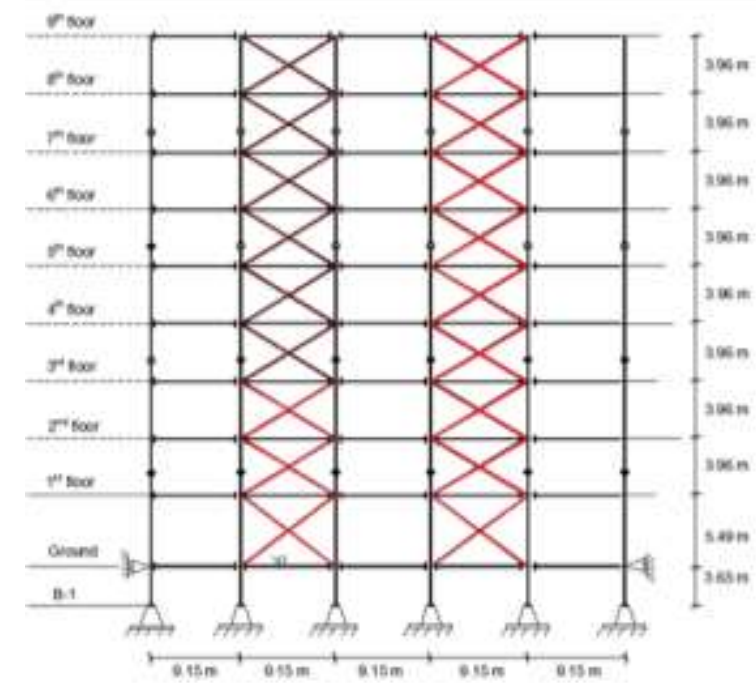

(a)

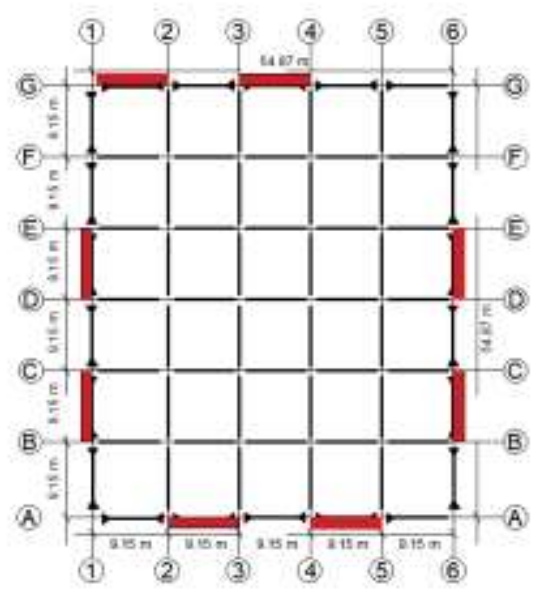

(c)

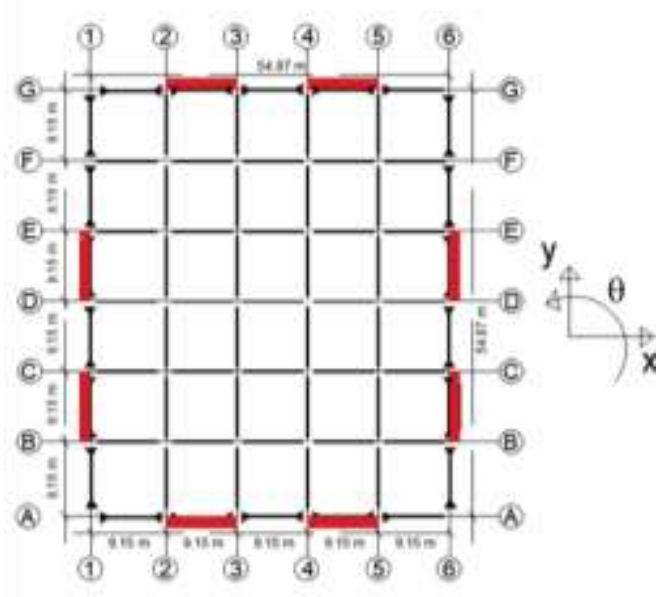

- Supplemental x-bracing frame

(b)

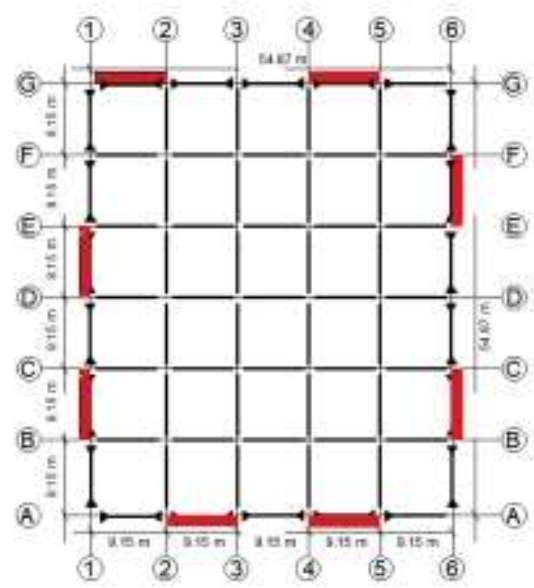

(d)

Figure 4. Different placements of the $x$-bracing system in moment resisting frames (MRFs): (a) A-A elevation view of Benchmark building, (b) in the plan view for Case 1 and $x$-bracing placement in the plan view of the Benchmark building for (c) Case 2 and (d) Case 3. 
Table 2. The geometric property and the contributions of the used cross-frame systems into MRFs

\begin{tabular}{|c|c|c|c|c|c|c|c|c|c|c|}
\hline \multirow[b]{2}{*}{$\begin{array}{l}\text { Story } \\
\text { no }\end{array}$} & \multirow[b]{2}{*}{ Brace } & \multicolumn{4}{|c|}{ Geometric property } & \multirow[b]{2}{*}{$\begin{array}{l}\mathbf{r}_{b r} \\
(\mathbf{m})\end{array}$} & \multirow[b]{2}{*}{$\begin{array}{l}\text { Angle } \\
\text { (Ø) }\end{array}$} & \multicolumn{2}{|c|}{ Contributions } & \multirow[b]{2}{*}{$\begin{array}{l}\text { Torsional } \\
\text { stiff. (N/m) }\end{array}$} \\
\hline & & $\begin{array}{l}\mathbf{A}_{\mathbf{c}} \\
(\mathbf{m})\end{array}$ & $\begin{array}{l}A_{b r} \\
(\mathbf{m})\end{array}$ & $\begin{array}{l}\mathrm{W} \\
(\mathrm{kg} / \mathrm{m})\end{array}$ & $\begin{array}{l}\mathbf{L}_{b r} \\
(\mathbf{m})\end{array}$ & & & $\begin{array}{l}\text { W } \\
(\mathrm{kg})\end{array}$ & $\begin{array}{l}\text { Lateral } \\
\text { Stiff. } \\
\text { (N/m) }\end{array}$ & \\
\hline 1 & HSS $14 \times 14 \times 7 / 8$ & 0.03 & 3.13 & 20.68 & 2.77 & 10.67 & 30 & 3530.70 & $1.06 \mathrm{E}+09$ & $2.18 \mathrm{E}+10$ \\
\hline 2 & HSS $14 \times 14 \times 7 / 8$ & 0.03 & 3.13 & 20.68 & 2.77 & 9.97 & 23 & 3298.93 & $6.95 \mathrm{E}+08$ & $1.39 \mathrm{E}+10$ \\
\hline 3 & HSS $12 \times 12 \times 5 / 8$ & 0.02 & 2.70 & 12.90 & 2.39 & 9.97 & 23 & 2057.84 & $4.41 \mathrm{E}+08$ & $8.91 \mathrm{E}+09$ \\
\hline 4 & HSS $12 \times 12 \times 5 / 8$ & 0.02 & 2.70 & 12.90 & 2.39 & 9.97 & 23 & 2057.84 & $4.41 \mathrm{E}+08$ & $8.91 \mathrm{E}+09$ \\
\hline 5 & HSS $12 \times 12 \times 5 / 8$ & 0.02 & 2.70 & 12.90 & 2.39 & 9.97 & 23 & 2057.84 & $4.41 \mathrm{E}+08$ & $8.91 \mathrm{E}+09$ \\
\hline 6 & HSS $12 \times 12 \times 5 / 8$ & 0.02 & 2.70 & 12.90 & 2.39 & 9.97 & 23 & 2057.84 & $4.41 \mathrm{E}+08$ & $8.91 \mathrm{E}+09$ \\
\hline 7 & HSS $10 \times 10 \times 5 / 8$ & 0.01 & 2.26 & 10.55 & 2.01 & 9.97 & 23 & 1682.96 & $3.43 \mathrm{E}+08$ & $7.01 \mathrm{E}+09$ \\
\hline 8 & HSS $10 \times 10 \times 5 / 8$ & 0.01 & 2.26 & 10.55 & 2.01 & 9.97 & 23 & 1682.96 & $3.43 \mathrm{E}+08$ & $7.01 \mathrm{E}+09$ \\
\hline 9 & HSS $8 \times 8 \times 1 / 2$ & 0.01 & 1.82 & 6.75 & 1.61 & 9.97 & 23 & 1076.78 & $2.21 \mathrm{E}+08$ & $4.56 \mathrm{E}+09$ \\
\hline
\end{tabular}

\subsection{Analysis Method}

Time history analysis (THA) is dynamic analysis. Most of the seismic codes [29,30] discourage usage because of the long-time required in the simulation analysis compared to other under-recorded earthquake data. Response spectrum analysis (RSA) is mostly preferred instead of the THA. However, The THA is a more trustworthy analysis method to assess the system dynamic response while others provide just approximate-solution.

Assuming that all structural members perform in the elastic range, and all nonlinearity, including materials or geometric, are not considered for THA analysis. The Benchmark building, including or not CFs placements as a linear time-invariant (LTI) system, is modeled as a state-space method employed in Simulink to compute structural responses easily. The analytical models need to be accurately constructed and coded in the structural analytical program package to perform structural responses in the THA for the structure with or without the different CFs placements. Therefore, the THA simulations were performed in Matlab \& Simulink [31] in this study, and the results for each case were obtained and saved for evaluation purposes.

\subsection{Ground Motion Selections}

There are a lot of strong earthquakes that have been occurred in the last century. The performance of the energy dissipating system like cross bracing frames mostly depends upon the earthquake input characteristics. Therefore, in this study, three bidirectional historical earthquakes represent typical xdominant, y-dominant, and both are determined to test the energy dissipating system, see Figure 5a, Figure 5b, and Figure 5c. 

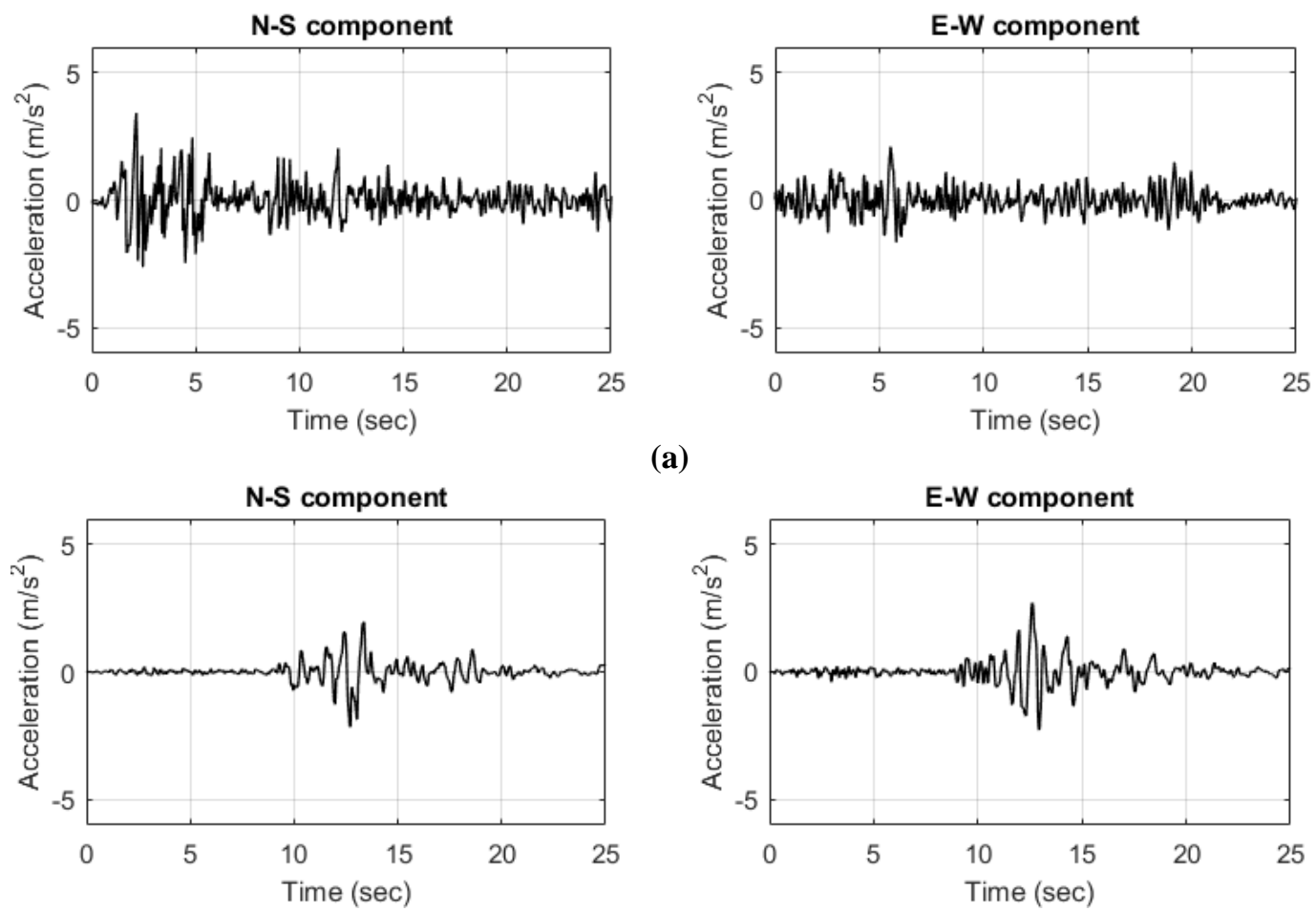

(a)
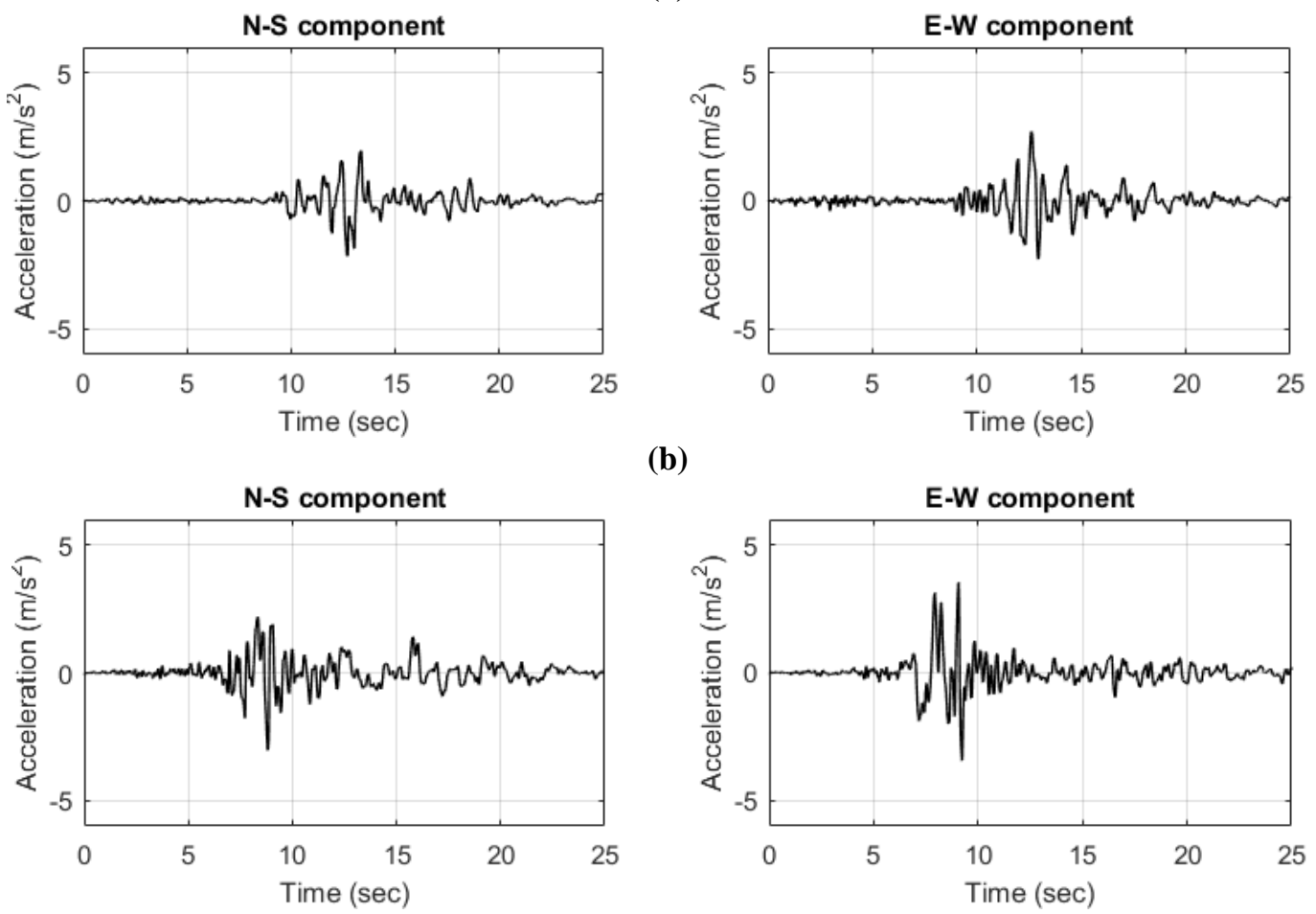

(b)

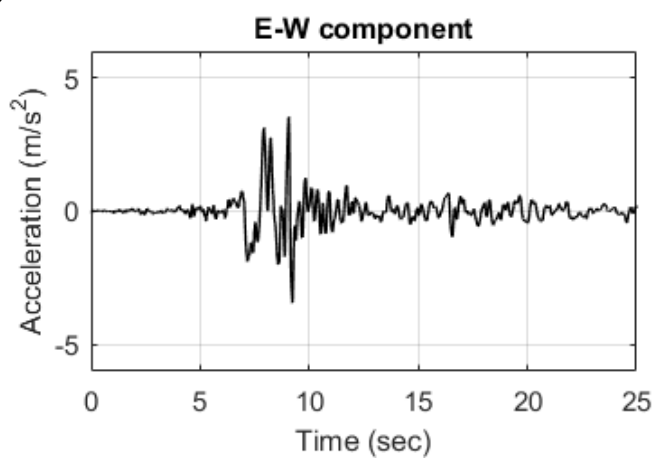

(c)

Figure 5. Three bidirectional historical real-life earthquakes: (a) El Centro, (b) Loma Prieta, and (c) Kocaeli earthquake

\section{Results and Discussion}

Benchmark 9-story steel structure is acquired as a reference structure, and the time history analyses are made by retrofitting the structure with three different CFs placements. The fundamental modal frequencies for all model structures are obtained and given in Table 4. As understood from it, whereas the contribution of the CFs placement into the lateral bearing system of the Benchmark building increases overall of the natural frequencies, for instance, the first mode is increased by $12 \%$ (from 7.71 to 8.69), which generally dominates total response of the structures, see Table 4. Moreover, it increases the load capacity in the lateral and torsional directions. As looking into CFs placements (Case 1; Case 2 ; and case 3), they all have a slightly different modal frequency in the lateral directions ( $\mathrm{x}-$ and $\mathrm{y}-$ ) thanks to HSS selection of the bracing elements. It improves the lateral loading capacity equally in the $\mathrm{x}$ - and $\mathrm{y}$ - direction; however, the building with Case 3 placement is more restricted against torsional motions. This fact can occur that the CFs placement in Case 3 can eliminate the eccentricity between $\mathrm{CM}$ and CS successfully compared to other placements and the bare structure. Therefore, Case 3 has the minimum modal frequency $(26.26 \mathrm{rad} / \mathrm{s})$ in the torsional direction. 
Table 3. Calculated eccentricities in both orthogonal directions for the bare Benchmark building, Case 1 , Case 2, and Case 3

\begin{tabular}{|c|c|c|c|c|c|c|c|}
\hline \multicolumn{2}{|c|}{ The bare Benchmark } & \multirow{2}{*}{$\begin{array}{l}\text { Case 1 } \\
e_{x}(m)\end{array}$} & \multirow[b]{2}{*}{$\mathbf{e}_{\mathbf{y}}(\mathbf{m})$} & \multicolumn{2}{|l|}{ Case 2} & \multicolumn{2}{|l|}{ Case 3} \\
\hline $\mathbf{e}_{\mathbf{x}}(\mathbf{m})$ & $\mathbf{e}_{\mathbf{y}}(\mathbf{m})$ & & & $\mathbf{e}_{\mathbf{x}}(\mathbf{m})$ & $\mathbf{e}_{\mathbf{y}}(\mathbf{m})$ & $\mathbf{e}_{\mathbf{x}}(\mathbf{m})$ & $\mathbf{e}_{\mathbf{y}}(\mathbf{m})$ \\
\hline 6.63 & 1.76 & 4.21 & -2.58 & 2.53 & -2.58 & 3.37 & -1.01 \\
\hline 3.53 & 1.23 & 2.58 & -1.76 & 1.34 & -1.76 & 1.96 & -0.58 \\
\hline 7.67 & 3.07 & 6.12 & 0.12 & 5.20 & 0.12 & 5.66 & 1.00 \\
\hline 6.18 & 2.38 & 4.84 & -0.52 & 3.86 & -0.52 & 4.35 & 0.44 \\
\hline 3.32 & 1.19 & 2.52 & -1.52 & 1.42 & -1.52 & 1.97 & -0.45 \\
\hline 2.16 & 0.75 & 1.60 & -1.92 & 0.42 & -1.92 & 1.01 & -0.77 \\
\hline 1.75 & 0.80 & 1.27 & -1.64 & 0.01 & -1.64 & 0.64 & -0.60 \\
\hline 1.58 & 0.79 & 1.09 & -1.73 & -0.31 & -1.73 & 0.39 & -0.65 \\
\hline 1.21 & 0.73 & 0.92 & -1.11 & -0.20 & -1.11 & 0.36 & -0.31 \\
\hline
\end{tabular}

Most of the structure in the real-life is likely to undergo unequally-distributed-eccentricity for each level because of the unequal distribution of structural components like columns, beams, and so on, and material and ground motion uncertainties. With consideration of these facts, three-historical earthquake ground motions are selected, and the size of used cross frames (HSS section) is assigned according to the fact that shear force is decreasing with the height of the structure. The cross frames are only integrated into moment-resisting frames of the Benchmark building, as seen in Figure 4. For all cases (case 1, case 2, and case 3), the eccentricity calculation is made, including the contribution of the simple frames. As seen in Table 3, the eccentricity is not the same throughout structure height. Each floor has a different eccentricity by comparing to one another. The inclusion of cross-frame placements changes the eccentricity location sometimes in the left-hand side and right-hand side from the center of mass (CM). Therefore, some values are shown negative, and some are positive in Table 3, which indicates the relative eccentricity distance according to the CM.

Table 4. The fundamental modal properties of the model buildings

\begin{tabular}{llllll}
\hline \multirow{2}{*}{ Modes (rad/s) } & \multirow{2}{*}{ Dominant dir. } & \multicolumn{2}{c}{ Benchmark } & \multicolumn{3}{c}{ Cross frame placements } \\
& & build. & Case 1 & Case 2 & Case 3 \\
\hline 1st mode & y lateral & 7.71 & 8.69 & 8.69 & 8.69 \\
2nd mode & X lateral & 12.87 & 13.42 & 13.42 & 13.43 \\
3rd mode & y lateral & 20.88 & 23.55 & 23.55 & 23.55 \\
4th mode & $\Theta$ torsional & 26.19 & 26.28 & 26.29 & 26.26 \\
5th mode & x lateral & 33.25 & 34.84 & 34.84 & 34.86 \\
\hline
\end{tabular}

After time history analyses are made under three selected real saved earthquake ground motions, the peak responses of the placements of the CFs placements compared with one another, including the bare Benchmark building. The results show that all three cross-frame installations are substantially surpassed the lateral vibrations, and there are slight differences for the peak response of the cross-frame placements. However, for torsional vibration control, only Case 3 is significantly reduced for both tuning and detuning loading scenarios, see Table 5. In the case of the El Centro earthquake, Case 1 (0.132) and Case $2(0.130)$ placements even increase the torsional effects in comparison with the bare structure. Moreover, Case 3 gives the best performance with the values (0.08 (32\% decrease); $0.071(50 \%$ decrease); and 0.133 ( $31 \%$ decrease) for the response reduction in the torsional direction for all earthquake loading cases, besides, the response reduction in the lateral directions.

Table 5. The maximum response of the case structures under bidirectional loadings, units; $\mathrm{cm}$ and $10^{-3} \mathrm{rad}$

\begin{tabular}{|c|c|c|c|c|c|c|c|c|c|}
\hline \multirow[t]{2}{*}{ Structure } & \multicolumn{3}{|c|}{$\begin{array}{l}\text { El Centro } \\
\text { Peak response }\end{array}$} & \multicolumn{3}{|c|}{$\begin{array}{l}\text { Loma Prieta } \\
\text { Peak response }\end{array}$} & \multicolumn{3}{|c|}{$\begin{array}{l}\text { Kocaeli } \\
\text { Peak response }\end{array}$} \\
\hline & $\mathrm{x}-$ & $y-$ & $\theta-$ & $\mathrm{x}-$ & $y-$ & $\theta-$ & $x-$ & $y-$ & $\theta-$ \\
\hline $\begin{array}{l}\text { Bare } \\
\text { Benchmark }\end{array}$ & 8.24 & 10.65 & 0.11 & 4.38 & 17.10 & 0.14 & 6.29 & 13.18 & 0.19 \\
\hline Case 1 & 6.85 & 7.46 & 0.13 & 3.67 & 16.82 & 0.12 & 5.80 & 10.37 & 0.16 \\
\hline Case 2 & 6.85 & 7.46 & 0.13 & 3.66 & 16.85 & 0.08 & 5.81 & 10.39 & 0.14 \\
\hline Case 3 & 6.87 & 7.45 & 0.08 & 3.67 & 16.85 & 0.07 & 5.82 & 10.39 & 0.13 \\
\hline
\end{tabular}


Overall, the CFs placement of Case 3 is so effective, especially in controlling torsional response as compared to other as well as in the lateral directions by significantly eliminating the eccentricity in the plan configuration.

\section{Conclusion}

Unlike using sophisticated modern control systems, the traditional energy dissipating devices with the right engineering design perspective can be useful as much as the modern control systems. Therefore, this study aims to observe and test the effects of CFs placements when the retrofitted structure is exposed to bidirectional three historical ground motions that might cause either tuning or detuning effects. The conclusions stated below can be figured out from the time history analysis results:

1. The contribution of the CFs placement into the moment resisting frames of the Benchmark building increases overall of the natural frequencies, for instance, the first mode is increased by $12 \%$ for all three loading cases, which generally dominates the total response of the structures.

2. The inclusion of cross frames struts into the moment frame in a structure has significant effects on the structural dynamics and stability. When they are integrated into the bare Benchmark building, it changes the eccentricity between the center of mass and stiffness for each floor significantly by increasing the structural lateral and torsional loading capacity effectively. Using them in the design of the structure with no torsional irregularity is not always the right way to follow because it may lead to unevenly distributed stiffness in the plan and elevation. Therefore, it can be convenient to have an engineering investigation on the system dynamic and stability, including additional energy dissipating systems before applying them.

3. All three cross-frame placements are successfully surpassed the lateral vibrations and slightly different for the peak response of the cross frame placements. However, only Case 3 is significantly reduced for both tuning El Centro (32\% decrease) and detuning Loma Prieta (50\% decrease), and Kocaeli ( $31 \%$ decrease) for torsional vibration control.

4. Overall, the CFs placement of Case 3 is a right engineering design perspective that is so effective, especially in controlling torsional response as compared to others as well as in the lateral directions by significantly eliminating the eccentricity in the plan configuration.

\section{Author's Contributions}

Corresponding author, OA, has performed and conducted on all stages of this research; the novelty of the research idea, theory, and its application, simulation and results, writing stage, and so forth.

\section{Statement of Conflicts of Interest}

The author declared no potential conflicts of interest for the research, authorship, and/or publication of this article.

\section{Statement of Research and Publication Ethics}

It is declared that the author has obeyed the rule(s) of the Research/Publication Ethics.

\section{References}

[1] Arslan MH, Korkmaz HH. What is to be learned from damage and failure of reinforced concrete structures during recent earthquakes in Turkey? Eng Fail Anal 2007;14:1-22. doi:10.1016/j.engfailanal.2006.01.003.

[2] Gokdemir H, Ozbasaran H, Dogan M, Unluoglu E, Albayrak U. Effects of torsional irregularity to structures during earthquakes. Eng Fail Anal 2013;35:713-7. doi:10.1016/j.engfailanal.2013.06.028.

[3] Iş1k E, Özdemir M, Karaşin İB. Performance Analysis of Steel Structures with A3 Irregularities. Int J Steel Struct 2018;18:1083-94. doi:10.1007/s13296-018-0046-6.

[4] Šipoš TK, Hadzima-Nyarko M. Seismic risk of croatian cities based on building's vulnerability. 
Teh Vjesn 2018;25:1088-94. doi:10.17559/TV-20170708190145.

[5] Işik E, Işik MF, Bülbül MA. Web based evaluation of earthquake damages for reinforced concrete buildings. Earthq Struct 2017;13:387-96. doi:10.12989/eas.2017.13.4.387.

[6] Güler K, Celep Z. On the general requirements for design of earthquake resistant buildings in the Turkish Building Seismic code of 2018. IOP Conf. Ser. Mater. Sci. Eng., vol. 737, Institute of Physics Publishing; 2020, p. 012015. doi:10.1088/1757-899X/737/1/012015.

[7] Moon DS. Integrated Seismic Assessment and Design Of Plan-Irregular Structures. University of Illinois at Urbana-Champaign, 2012.

[8] Akyürek O. Lateral and Torsional Seismic Vibration Control for Torsionally Irregular Buildings. Florida Institute of Technology, 2019.

[9] Damjan M, Fajfar P. On the inelastic seismic response of asymmetric buildings under bi-axial excitation. Earthq Eng Struct Dyn 2005;34:943-63. doi:10.1002/eqe.463.

[10] Satheesh AJ, Jayalekshmi BR, Venkataramana K. Effect of in-plan eccentricity in vertically mass irregular RC framed buildings under seismic loads. Asian J Civ Eng 2019;20:713-26. doi:10.1007/s42107-019-00138-w.

[11] Akyürek O, Suksawang N, Hiong T. Vibration control for torsionally irregular buildings by integrated control system. Eng Struct 2019;201:109775. doi:10.1016/j.engstruct.2019.109775.

[12] Li C. Performance of multiple tuned mass dampers for attenuating undesirable oscillations of structures under the ground acceleration. Earthq Eng Struct Dyn 2000;29:1405-21. doi:10.1002/1096-9845(200009)29:9<1405::AID-EQE976>3.0.CO;2-4.

[13] $\mathrm{Xu} \mathrm{K}$, Igusa T. Dynamic characteristics of multiple substructures with closely spaced frequencies. Earthq Eng Struct Dyn 1992;21:1059-70. doi:10.1002/eqe.4290211203.

[14] Park J, Reed D. Analysis of uniformly and linearly distributed mass dampers under harmonic and earthquake excitation. Eng Struct 2001;23:802-14. doi:10.1016/S0141-0296(00)00095-X.

[15] Lavan O. Multi-objective optimal design of tuned mass dampers. Struct Control Heal Monit 2017;24:e2008. doi:10.1002/stc.2008.

[16] Gill D, Elias S, Steinbrecher A, Schröder C, Matsagar V. Robustness of multi-mode control using tuned mass dampers for seismically excited structures. Bull Earthq Eng 2017;15:5579-603. doi:10.1007/s10518-017-0187-6.

[17] Battistini AD, Wang WH, Helwig TA, Engelhardt MD, Frank KH. 2012. Comparison of the stiffness properties for various cross frame members and connections. Struct. Stab. Res. Counc. Annu. Stab. Conf., 244-257.

[18] Battistini AD. 2014. Stiffness and Fatigue Behavior of Cross Frames for Steel Bridge Applications. Doctoral Dissertation, University of Texas at Austin, Texas, USA.

[19] Emrah Erduran, Ryan KL. Effects of torsion on the behavior of peripheral steel-braced frame systems. Earthq Eng Struct Dyn 2010;40:491-507. doi:10.1002/eqe.

[20] Chen C-H, Lai J-W, Mahin SA. Seismic Performance Assessment of Concentrically Braced Frames. 13 World Conf Earthq Eng 2004:1-8. doi:10.1061/(ASCE)ST.1943-541X.0002276.

[21] Ülker M, Işık E, Ülker M. 2018. The Effect of Centric Steel Braced Frames with High Ductility Level on the Performance of Steel Structures. Frrat Univ Turkish J Sci Technol., 13: 61-64.

[22] Akyürek O. 2014. Betonarme Bina Performansina Dolgu Duvarlarin Etkisi (The effects of infill walls in RC building performance). Yüksek Lisans Tezi, Süleyman Demirel Üniversitesi Fen Bilimleri Enstitüsü, Isparta.

[23] Aksoylu C, Sezer R. Investigation of precast new diagonal concrete panels in strengthened the infilled reinforced concrete frames. KSCE J Civ Eng 2018;22:236-46. doi:10.1007/s12205-0171290-6.

[24] Ohtori Y, Christenson RE, Spencer BF, Dyke SJ. Benchmark Control Problems for Seismically Excited Nonlinear Buildings. J Eng Mech 2004;130:366-85. doi:10.1061/(ASCE)07339399(2004)130:4(366).

[25] Federal Emergency Management Agency (FEMA). FEMA 355F - State of the Art Report on Performance Prediction and Evaluation of Steel Moment-Frame Buildings. Fema-355F 2000;1:1-367.

[26] Chopra AK. Dynamics of Structures: Theory and Applications to Earthquake Engineering. vol. 23. Englewood Cliffs, N.J. : Prentice Hall; 2000. doi:10.1193/1.1586188.

[27] Helwig T, Engelhardt MD, Frank KH. Comparison of the Stiffness Properties for Various Cross 
Frame Members and Connections Comparison of the Stiffness Properties for Various Cross Frame Members and Connections 2012.

[28] Yura JA. Fundamentals of beam bracing. Eng Journal-American Inst Steel Constr 2001;38:1126.

[29] Society of Civil Engineers A. ASCE American Society of Civil Engineers Minimum Design Loads for Buildings and Other Structures This document uses both the International System of Units (SI) and customary units. 2006.

[30] AFAD ve Acil Durum Yönetimi Başkanlığı. Türkiye Bina Deprem Yönetmeliği. vol. 30364. 2018.

[31] MathWorks, M. A. T. L. A. B. 2016. SIMULINK for technical computing. Available on https://www.mathworks.com/ 2016. 